\title{
Appendiceal Carcinoma TNM Finding v7
}

National Cancer Institute

\section{Source}

National Cancer Institute. Appendiceal Carcinoma TNM Finding v7. NCI Thesaurus. Code C89892.

A finding about one or more characteristics of appendiceal carcinoma, following the rules of the TNM AJCC V7 classification system. 